\title{
Fertilizer Microdosing and "Warrantage" or Inventory Credit System to Improve Food Security and Farmers' Income in West Africa
}

\author{
R. Tabo, A. Bationo, B. Amadou, D. Marchal, F. Lompo, M. Gandah, O. Hassane, \\ M.K. Diallo, J. Ndjeunga, D. Fatondji, B. Gerard, D. Sogodogo, J.-B.S. Taonda, K. Sako, \\ S. Boubacar, A. Abdou, and S. Koala
}

\begin{abstract}
The fertilizer microdosing technology deals with the application of small quantities of fertilizers in the planting hole, thereby increasing fertilizer use efficiency and yields while minimizing input costs. In drought years, microdosing also performs well, because larger root systems are more efficient at finding water, and it hastens crop maturity, avoiding lateseason drought. Recent research found that solving the soil fertility problem unleashes the yield potential of improved millet varieties, generating an additional grain yield of nearly the same quantity. Recognizing that liquidity constraints often prevent farmers from intensifying their production system, the warrantage or inventory credit system helps to remove barriers to the adoption of soil fertility restoration. Using a participatory approach through a network of partners from the National Agricultural Research and Extension Systems (NARES), non-governmental organizations (NGOs), farmers and farmer groups and other international agricultural research centres, the microdosing technology and the warrantage system have been demonstrated and promoted in Burkina Faso, Mali, and Niger during the past few years with encouraging results. Sorghum and millet yields increased by up to $120 \%$, and farmers' incomes went up by $130 \%$ when microdosing was combined with the warrantage system. This chapter highlights the outstanding past results and the ongoing efforts to further scale up the technology using Farmer field schools (FFS) and demonstrations, capacity and
\end{abstract}

R. Tabo $(\bowtie)$

Forum for Agricultural Research in Africa (FARA),

Accra, Ghana

e-mail: rtabo@fara-africa.org institutional strengthening, private sector linkages and crop diversification amongst other approaches.

Keywords Farmer field schools • Fertilizer microdosing • Millet . Participatory approach . Sorghum - Warrantage or inventory credit system

\section{Introduction}

Poverty and food insecurity continue to create suffering across the semi-arid Sudano-Sahelian zone of West Africa. Unpredictable droughts cause food shortages for both humans and the livestock on which they depend. The predominantly sandy soils in this zone are of very low fertility, particularly in phosphorus $(\mathrm{P})$ and nitrogen $(\mathrm{N})$, with phosphorus being more limiting to crop growth and yield than is nitrogen (Bationo et al., 1998a, b). It was reported that crop response to nitrogen was minimal when crop phosphorous requirements were not met (Traore, 1974).

Sivakumar (1992) reported that the little arable land in the Sudano-Sahelian zones is being gradually reduced due to the southward creep of the $400-\mathrm{mm}$ isohyet as a consequence of land degradation, drought and other human activities. In addition, the high population growth rate (3.4\% per annum) and the increasing population density have put a lot of pressure on the cultivated lands, which leads to a significant decrease and disappearance, in some cases, of fallow lands. Because of this, farmers are increasingly being forced to cultivate marginal and degraded lands where moisture and nutrient stress significantly constrain crop production, which results in low yields and further land 
degradation. Stoorvogel and Smaling (1990) reported that because of these problems, increases in crop production have resulted more from the expansion of cultivated areas than from increased crop productivity.

It is widely believed that the only real cure against land hunger in the West African Sahel lies in the intensification of agriculture and in increased productivity of the arable land through the use of external inputs, mainly inorganic fertilizers (Van Keulen and Breman, 1990; Breman, 1990). Although soil fertility enhancement technologies have been developed over the years for the main staple food crops in West Africa, such as sorghum and millet, these technologies have not been adopted by resource-poor farmers due to the high costs and unavailability of the inputs as well as the inappropriateness of the fertilizer recommendations made which are very high and not affordable by farmers. As a consequence of this, the productivity of the major staple food crops such as sorghum and millet has continued to decrease.

To address these constraints and increase the productivity of these major staple food crops, various national and international research institutions working in the Sahel joined forces through a collaborative research program and developed an effective technique to increase fertilizer use efficiency and reduce investment costs for resource-poor, small-scale farmers, thereby increasing crop growth and productivity (Bationo et al., 1998a, b; Buerkert and Hiernaux, 1998). This strategic application of fertilizer, also known as fertilizer microdosing, is based on applying small doses of fertilizer in the hill of the target grain crop at planting rather than broadcasting it all over the field. The microdosing technology is affordable to the poor because of the reduced investment cost, and it gives a quick start, thus avoiding early season drought, and an earlier finish, avoiding end-of-season drought while increasing crop yields (Tabo et al., 2006, 2007).

It is not enough to grow more. What is even more important is that farmers should get the right price for their product (i.e. grains) so as to increase their income and improve their livelihoods. Rather than selling their grain into a glutted market for low prices at harvest time, in the Warrantage or inventory credit system, farmers (or producer organizations) stock their produce at harvest in the warehouses of the farmers' associations and are issued cash loans. These loans enable them to meet immediate family cash needs, participate in collective fertilizer (and other input) purchases and carry out their income-generating activities during the off-season like fattening of small ruminants, vegetable gardening and trading. They then sell the stored grains at higher prices when the market supply begins to decline 4-5 months after harvest and pay back their loans with interest.

The warrantage system is used as a link between credit and cereal grain markets. This credit facility removes the barriers to the adoption of soil fertility restoration technologies. In order to make inputs accessible to farmers, sustainable farmer-based enterprises and cooperative organizations are developed, storage facilities and inputs shops (boutique d' intrants) are built, and credit and savings schemes are also developed. These facilities are managed by members of these cooperatives. Linking farmers to input or product markets and the vertical integration between these become prerequisites to the uptake of agricultural technologies. Efforts to develop institutional arrangements likely to improve the linkages of rural households to major markets are often major developmental challenges. The combination of fertilizer microdosing with the complementary institutional and market linkages, through the warrantage system, offers an excellent option for improving crop productivity and increasing farmers' incomes in the semi-arid Sudano-Sahelian zone of West Africa. The warrantage credit facility was initiated in Niger in the late 1990s to remove barriers to the adoption of soil fertility restoration inputs.

ICRISAT is working closely with Projet Intrants, FAO, several NGOs, national and international research organizations, development agencies, extension services and other stakeholders to help farmers develop and strengthen cooperatives. In the past few years, USAID assisted ICRISAT to complement FAO's efforts for demonstrating and promoting the fertilizer microdosing technology and the warrantage system in Burkina Faso, Mali and Niger. Recently we won a competitive grant from the West and Central African Council for Agricultural Research and Development (CORAF/WECARD), with funds from the African Development Bank to pursue our efforts to disseminate the technology in West Africa. We are also exploring other sources of funding to scale up and out this promising technology to millions of farmers across the West and Central African regions. This chapter reports the encouraging and good results that were 
obtained from on-farm evaluation trials and demonstrations of the technology in three selected countries in West Africa, namely Burkina Faso, Mali and Niger, and also discusses the future perspectives for wider dissemination across the region.

\section{Materials and Methods}

Demonstrations and on-farm trials involving microdosing technology were conducted in Burkina Faso, Mali and Niger between 1998 and 2006. These field experiments were designed by the researchers but were managed by the farmers themselves, with training and technical backstopping from extension agents, NGOs and scientists. Experimental plots and types of fertilizers used varied between study sites depending on the local conditions and the availability of these inputs.

\section{On-farm Field Experiments}

These on-farm field tests included demonstration plots and farmer field schools (FFS') using the fertilizer microdosing technology. The demonstration tests consisted of three plots per farmer, each plot measuring approximately $300 \mathrm{~m}^{2}$. Three treatments consisted of the farmers' practice, the earlier recommended broadcasting system of fertilizer application (about $100 \mathrm{~kg}$ NPK (15:15:15) per ha) and the fertilizer microdosing at 4-6 g per hill of compound fertilizer (NPK) (40-60 kg NPK per ha) or $2 \mathrm{~g}$ of diammonium phosphate (DAP) per hill (20 kg DAP per ha). The test crops used were millet and sorghum. Plant densities under farmer conditions varied between 5,000 and 6,000 hills per ha, while the recommended densities in the microdosing plots varied from 10,000 to 20,000 hills per ha.

Farmers were given the option to plant their fields whenever they felt that the soil was moist enough for germination of seeds. They used their own densities in the control plots but were requested to follow the recommended densities in the microdosing plots, with guidance from the field technicians. They also weeded when it is time to do so, in some cases, on the advice of field technicians. Harvesting is done by farmers under the supervision of field technicians. Data collection was done by the field technicians.
In Burkina Faso, 30 villages and 210 farmers in the northern, central north zone were involved in these studies. In Mali the on-farm trials were carried out in 44 villages in the regions of Mopti, Segou, Koulikoro, Mande and Beledougou with 321 farmers. In Niger, approximately 1,536 demonstrations and field experiments were established in 254 villages in five departments in southern Niger, namely Tillabery, Dosso, Tahoua, Maradi and Zinder.

\section{Socio-economic Assessment}

In addition to the field trials, a socio-economic evaluation was carried out to assess the economic performance of the fertilizer microdosing technology. Net gain was calculated as the difference between the total revenues from the grain and the total cost of fertilizer as follows:

$$
\mathrm{NG}=\mathrm{R}-\mathrm{C}
$$

where NG is the net gain; $\mathrm{R}$ is the revenue from grains; and $\mathrm{C}$ is the cost of fertilizer.

Net gain was expressed in Franc Communauté Financière Africaine (FCFA) per hectare. The cost of labour was not used as the data were collected from plots that are not large enough and the data were not reliable.

In November/December 2004, surveys were conducted to assess the effect of input shops on fertilizer use and crop yield. These surveys involved 10 villages and 10 input shops.

\section{Capacity-Building Activities}

Field technicians, extension agents and farmers in all the three participating countries were trained in the laying out of the demonstration plots and farmer field schools and the appropriate method of using the fertilizer microdosing technology. These training sessions demonstrated to them how to measure the recommended rate of fertilizer (microdose) in the field, how to apply it correctly in the field and how to manage the field after sowing. Emphasis was also put on the best way of collecting agronomic as well as socioeconomic data from the trial set up. Several training sessions were given to farmers' organizations on the warrantage system. 


\section{Results}

\section{Microdosing Performance by Agro-ecological Zones}

In all the three agro-ecological zones - Sahelian (400-600 mm), Sudano-Sahelian (600-1000 mm) and Sudano-Guinean $(>1000 \mathrm{~mm})$, sorghum under the microdose yielded higher than under the earlier recommended rates of broadcasting and the farmers' traditional practice (Fig. 1). The yield advantage of the microdose over the farmers' practice varied from 50 to $100 \%$. As it is expected, yields were generally higher in the wetter Sudano-Guinean zone $\left(1500 \mathrm{~kg} \mathrm{ha}^{-1}\right)$ than in the drier Sahelian zone $\left(750 \mathrm{~kg} \mathrm{ha}^{-1}\right)$. This is due to the higher rainfall amount and to the better distribution of the rainfall in the Sudano-Guinean zone during the growing season, which reduces the risk of crop failure.

\section{Burkina Faso}

\section{Grain Yields}

Throughout the study period covering the cropping seasons from 2002 to 2006, the microdose treatments yielded, on average, higher than did the farmers' traditional practice. Millet grain yields ranged from $44 \%$ in 2002 to $101 \%$ in 2005 , while sorghum grain yields under microdose were 47 and 106\% higher than the control in 2002 and 2005, respectively (Figs. 2 and 3). Sorghum and millet performed better in 2005 due to a better rainfall distribution during the growing period. In 2006, millet and sorghum grain yields were 64 and 90\% higher, respectively, under microdose than with the farmers' practice.

\section{Net Gains from Microdosing}

Farmers obtained returns from their millet with microdose that were three times higher than the revenue from the broadcasting method (12575 FCFA ha ${ }^{-1}$ as compared to $5175 \mathrm{FCFA} \mathrm{ha}^{-1}$ ). The net gains for sorghum were approximately 2.5 times higher with microdose (22780 FCFA ha ${ }^{-1}$ vs 9255 FCFA ha $^{-1}$ ).

\section{Mali}

\section{Grain Yields}

Sorghum and millet performed better under microdose than with the broadcasting method and farmers' traditional practice. In 2002, millet and sorghum grain yields with the microdose were, on average, 61 and $107 \%$ higher, respectively, than the control (Figs. 4 and 5). In 2003, millet and sorghum grain yields from the microdosing treatments were 90 and $69 \%$ higher, respectively than the farmers' practice.
Fig. 1 Sorghum grain yield $\left(\mathrm{kg} \mathrm{ha}^{-1}\right)$ by agro-ecological zones, WCA

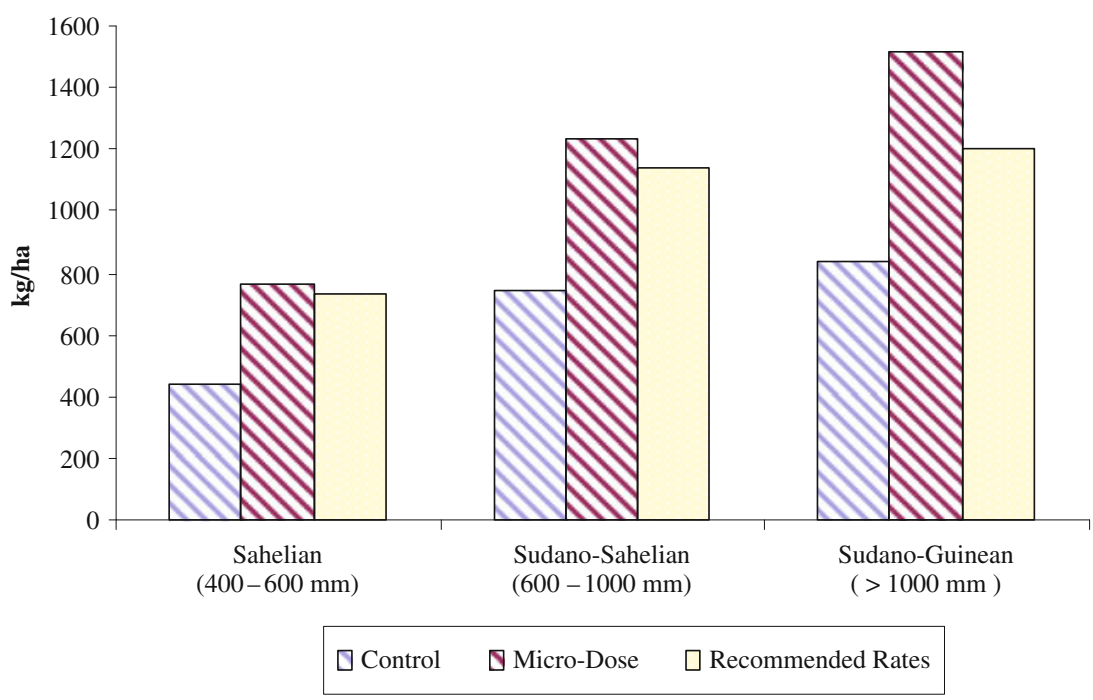


Fig. 2 Millet grain yield $\left(\mathrm{kg} \mathrm{ha}^{-1}\right)$ as affected by microdosing, Burkina, 2006

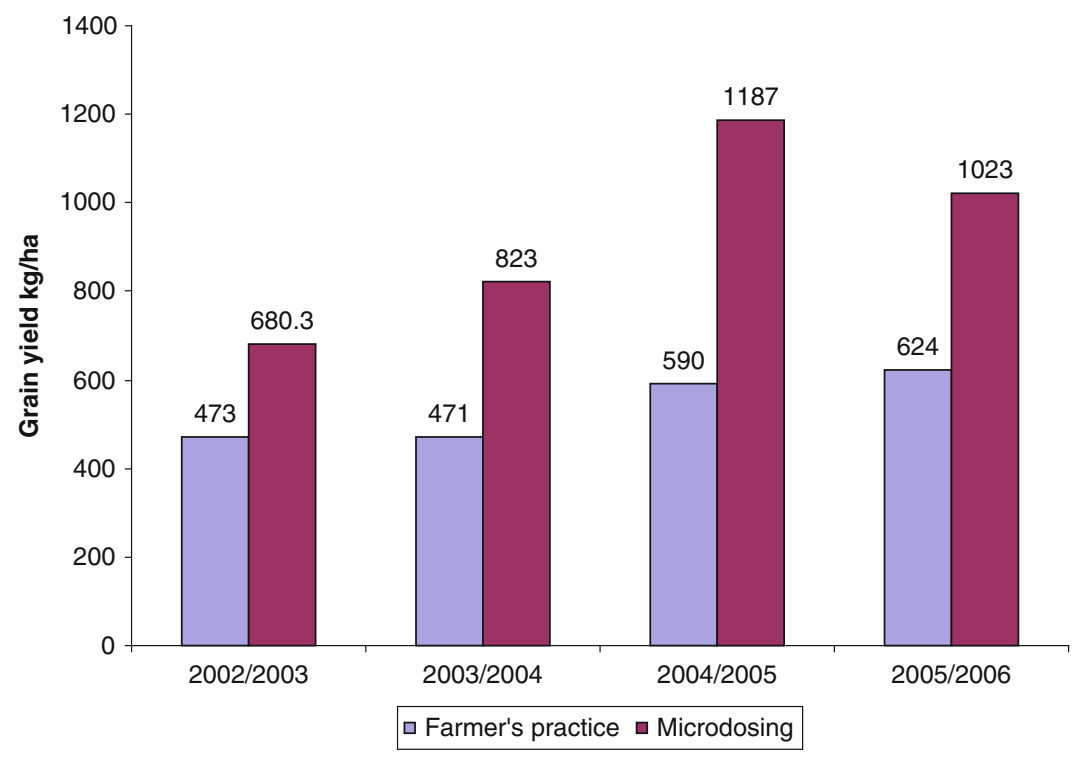

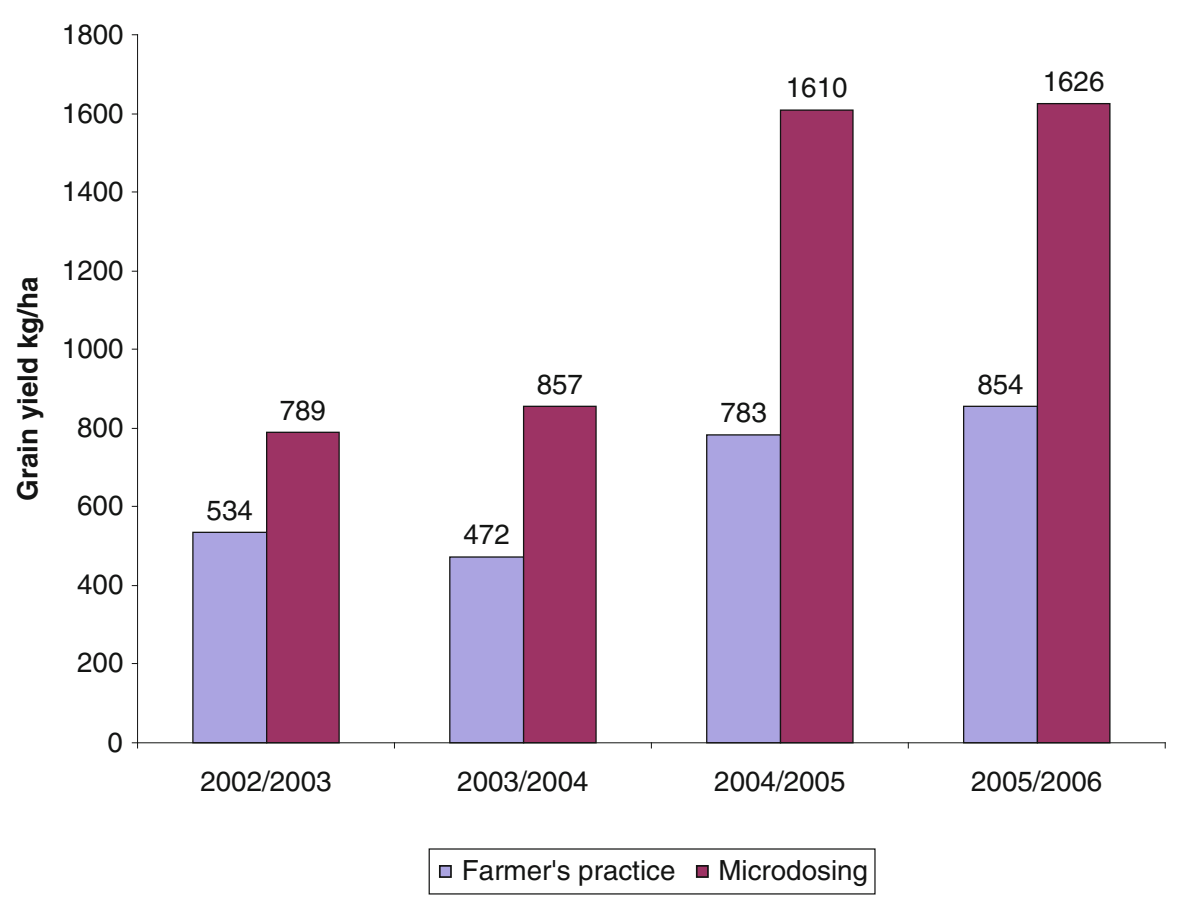

Fig. 3 Sorghum grain yield $\left(\mathrm{kg} \mathrm{ha}^{-1}\right)$ as affected by microdosing, Burkina, 2006 
Fig. 4 Millet grain yields $\left(\mathrm{kg} \mathrm{ha}^{-1}\right)$ for demonstration trials (control, microdose and recommended rates (RR)) in Mali, 2002 and 2003

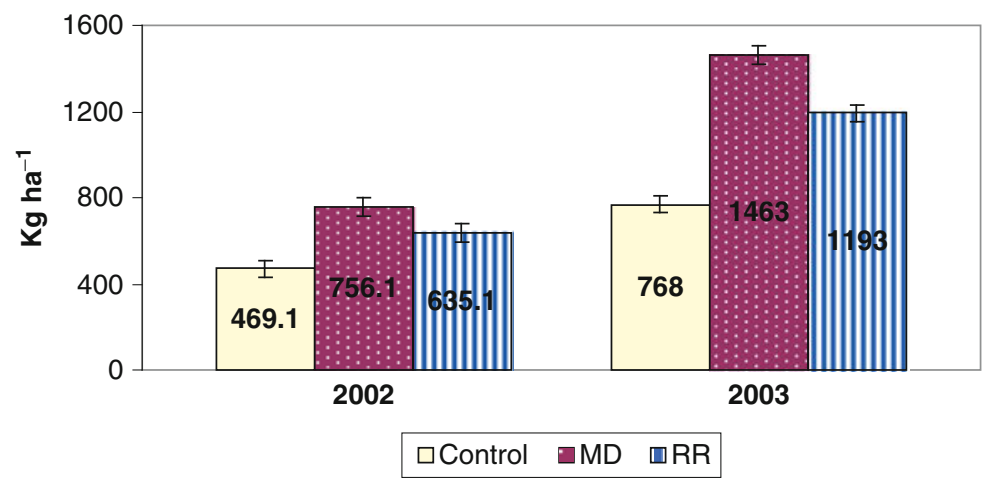

Fig. 5 Sorghum grain yields $\left(\mathrm{kg} \mathrm{ha}^{-1}\right)$ for demonstration trials (control, microdose and recommended rates (RR)) in Mali, 2002 and 2003

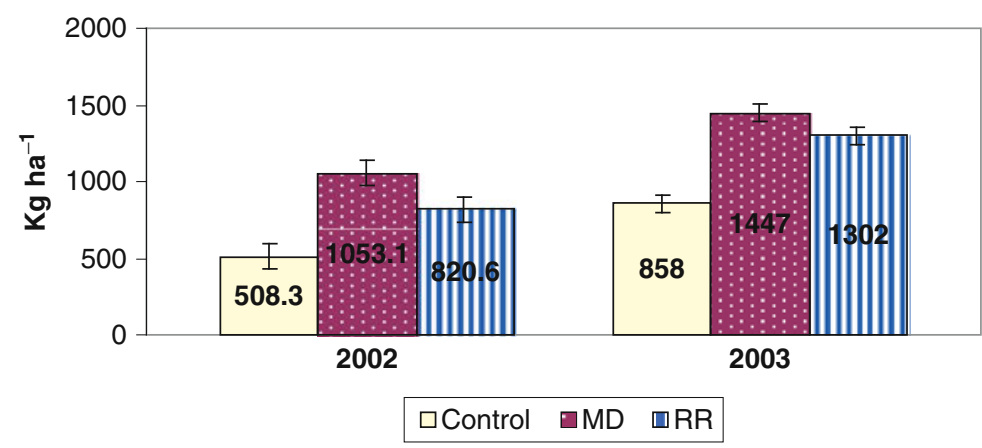

\section{Net Gains from Microdose}

Millet under microdose gave net monetary gains of 119690 FCFA ha ${ }^{-1}$ which were $68 \%$ higher than the net returns from the traditional practice ( 71167 FCFA $\mathrm{ha}^{-1}$ ) and $33 \%$ higher than the net gain from the broadcasting technique (89959 FCFA ha ${ }^{-1}$ ).

\section{Niger}

\section{Grain Yields}

In all agro-ecological zones, microdosing resulted in significant increase in grain yield (Fig. 6). There is significant yield increase at individual farmer's level due to microdosing of fertilizers. Grain yield increment from microdosing treatment over the control was as high as $89 \%$ with an average of $44 \%$ or about $300 \mathrm{~kg} \mathrm{ha}^{-1}$. Approximately half of the farmers (44\%) reported yield increase of at least $50 \%$, which is double the yield obtained from the farmers' practice.

\section{Net Returns from Microdosing}

In 2002, net returns were 74650 FCFA per ha for DAP + urea, 65642 FCFA per ha for DAP, 62619 FCFA per ha for NPK and 51745 FCFA per ha for the control. Net profits were, on average, 44 and $121 \%$ higher with the microdose than under the control plots in 2002 and 2003 , respectively.

\section{Effect of the Presence of Input Shops on Fertilizer Use and Crop Performance}

It was observed that the presence of input shops in a village has a positive effect on the intensity of fertilizer use as well as the crop yields. Figure 7 shows that on average, $5.52 \mathrm{~kg}$ of fertilizer per ha was used by farmers where input shops are established as compared to only $3.32 \mathrm{~kg}$ per ha in areas with no input shops. This translates to a higher grain yield from millet $\left(541 \mathrm{~kg} \mathrm{ha}^{-1}\right)$ where there are input shops, whereas 


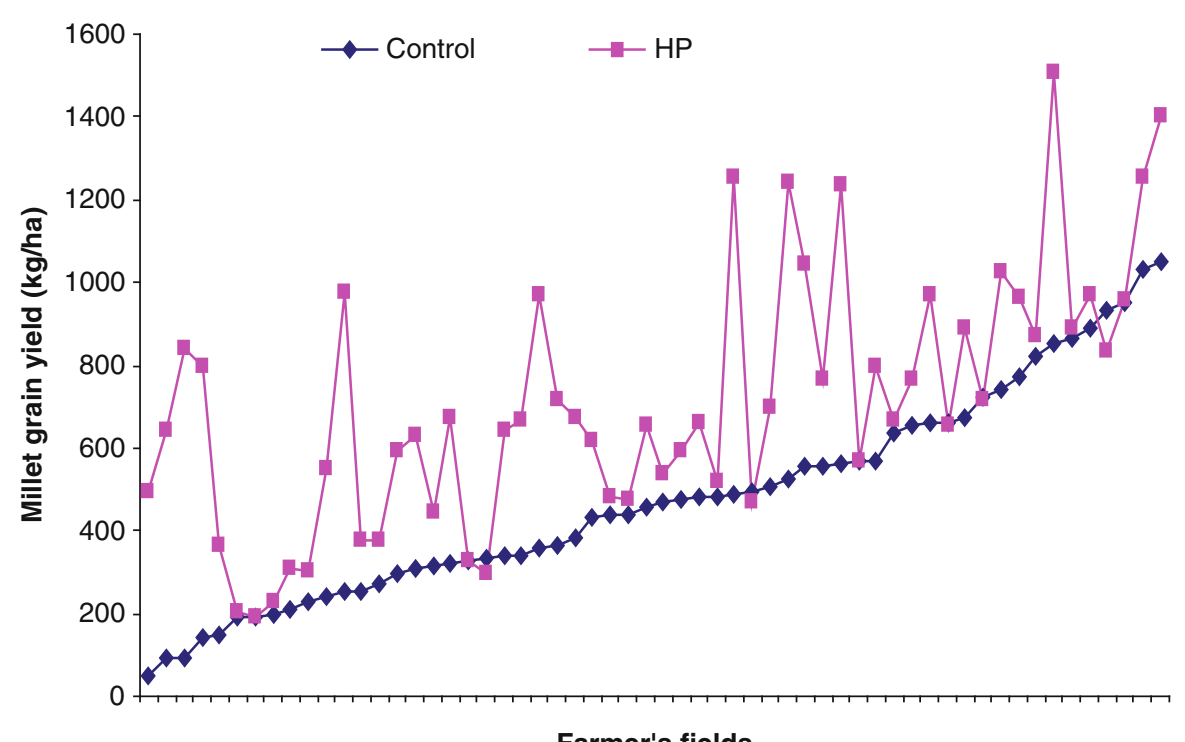

Fig. 6 Pearl millet grain response $\left(\mathrm{kg} \mathrm{ha}^{-1}\right)$ to microdose hill placement (HP) management, Niger, 1998-2000

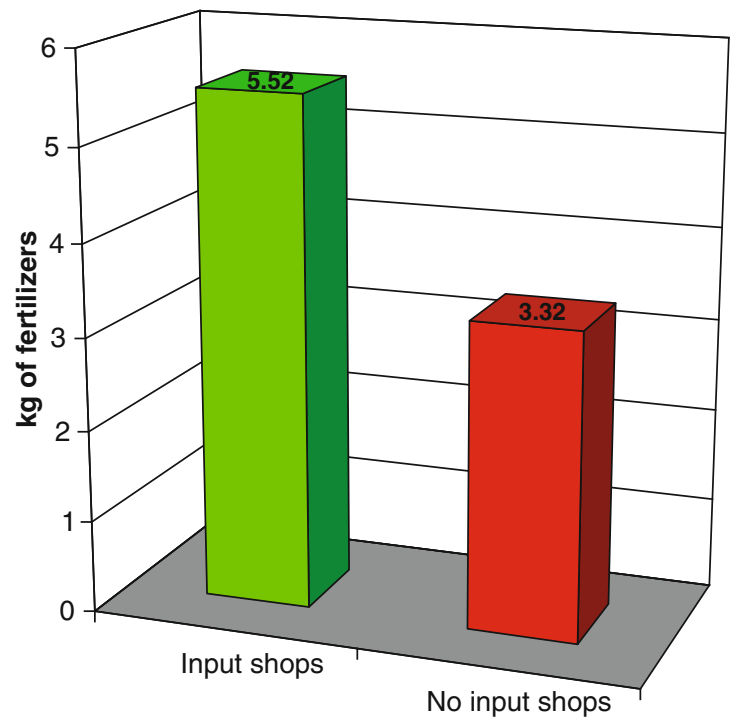

Fig. 7 Fertilizer use $\left(\mathrm{kg} \mathrm{ha}^{-1}\right)$ affected by the presence of input shop

grain yields were lower $\left(486 \mathrm{~kg} \mathrm{ha}^{-1}\right)$ (Fig. 8). The presence of input shops where small packs of fertilizers $(1,2$, or $5 \mathrm{~kg}$ of small pack) are sold enables farmers with limited resources to afford these small packs instead of trying to purchase 50-kg bags of fertilizers that are out of their reach financially.

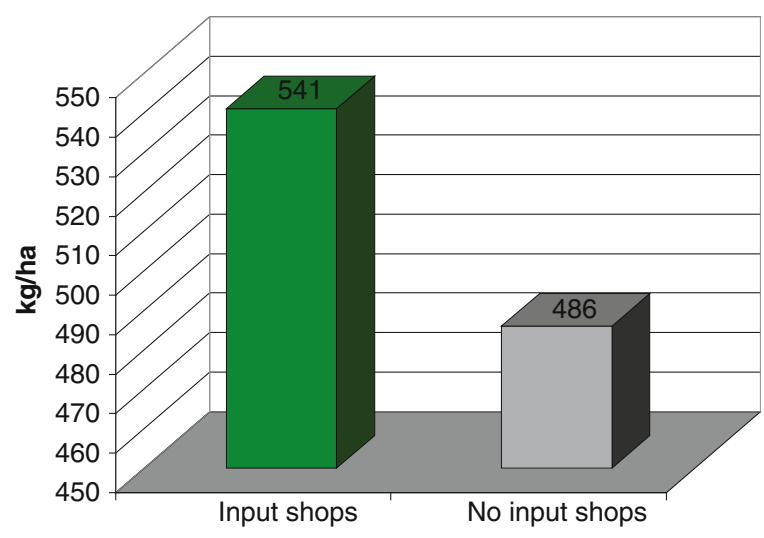

Fig. 8 Millet grain yield $\left(\mathrm{kg} \mathrm{ha}^{-1}\right)$ as affected by the presence of input shop

\section{'Warrantage' or Inventory Credit System}

The warrantage scheme enables the establishment of a link between credit and cereal grain markets. This credit facility removes the barriers to the adoption of soil fertility restoration technologies. Farmers can have access to credit to enable them purchase external inputs such as fertilizers and invest in income-generating activities like fattening of small ruminants, horticulture and trading while using the stored grains to get higher prices at a time when the market supply begins 
Table 1 Example of warrantage performance in Mali, 2002/2003

\begin{tabular}{|c|c|c|c|c|c|c|}
\hline NGO partner & Villages & Crops & $\begin{array}{l}\text { Quantity of } \\
\text { grain stored } \\
(\mathrm{kg}) \times 1000\end{array}$ & $\begin{array}{l}\text { Credit received } \\
\text { under "warrantage" } \\
(\text { FCFA }) \times 1000\end{array}$ & $\begin{array}{l}\text { Management } \\
\text { fees (FCFA) } \\
\times 1000\end{array}$ & $\begin{array}{l}\text { Net benefits } \\
\text { (FCFA) }\end{array}$ \\
\hline \multirow[t]{6}{*}{ SG 2000} & Kondogola & Millet & 4 & 360 (US \$720)* & 4 (US \$8) & $236($ US $\$ 472)$ \\
\hline & Niamabougou & Millet/sorghum & 28.5 & $4246.5(\$ 8493)$ & $1320(\$ 2640)$ & $922.5(\$ 1845)$ \\
\hline & & Paddy rice & 2 & $580(\$ 1160)$ & $79(\$ 158)$ & Consumed \\
\hline & Sélinkégny & Maize/millet & 3.8 & $482(\$ 964)$ & - & $29.4(\$ 59)$ \\
\hline & & Paddy rice & 4.2 & $420(\$ 840)$ & $100(\$ 200)$ & Consumed \\
\hline & Tioribougou & Sorghum & 4.1 & $619.5(\$ 1239)$ & $10.5(\$ 21)$ & $196(\$ 392)$ \\
\hline ADAF/Gallé & Kénioroba & Millet/Sorghum & 6.9 & $1141(\$ 2282)$ & - & $91.4(\$ 183)$ \\
\hline Winrock & Tissala & Millet/Sorghum & 6.2 & $620(\$ 1240)$ & $46.5(\$ 93)$ & $35(\$ 70)$ \\
\hline \multirow[t]{2}{*}{ International } & Sofara & Paddy rice & 13.1 & $638.4(\$ 1277)$ & - & $215.6(\$ 431)$ \\
\hline & & Sorghum & 0.9 & $126.3(\$ 252)$ & $49.9(\$ 100)$ & Consumed \\
\hline
\end{tabular}

Equivalence in US dollars (1 US $\$=500$ FCFA)

to decline. In order to make inputs accessible to farmers, sustainable farmer-based enterprises and cooperative organizations are developed, storage facilities and inputs shops (boutique d' intrants) are built and credit and savings schemes are also developed. These facilities are managed by members of these cooperatives. Table 1 shows that farmers were able to make substantial benefits by practising the warrantage system in Mali in 2002/2003.

\section{Discussion}

In this chapter, it was shown that the fertilizer microdosing technology has great potential to improve crop productivity. Overall grain yield increases using the microdosing technology were double the yields obtained from the farmer's traditional practice. Although it is believed that fertilizer microdosing gives the plant a quick start thereby enabling it to escape drought, higher yields are generally achieved under assured rainfall conditions such as in the SudanoGuinean zone. Net gains were obtained by farmers using this technology which is economically viable.

The fertilizer microdosing technology coupled with the warrantage system (credit scheme and input shops) is an entry point for the green revolution in Africa. This is a simple but efficient technology that is readily accessible to farmers. The role of input shops where small packs of fertilizers are sold is significant in making inputs available to and affordable by farmers. As farmers experiment with the small packs and are convinced of the benefits of the microdosing technology, they are willing to invest more and more in purchasing fertilizers, thereby increasing the intensity of fertilizer use.

An issue that requires further investigation is the possibility of soil mining arising from using the fertilizer microdosing technology. As grain yields increase per unit area and very little organic matter (OM), including crop residues, are returned into the soil, there is the risk that nutrient imbalances will inevitably develop with time. There is therefore a need to ensure that $\mathrm{OM}$ is added and incorporated into these soils to improve their structure so that their capacity to store adequate moisture and nutrients even after crops are harvested is enhanced.

Labour could also be a major constraint to the wide adoption of the fertilizer microdosing technology. To further reduce the cost-benefit ratio, efforts should be made to develop labour-saving equipment to complement the farmers' efforts. The precise application of the fertilizer microdose in the hill of the plant requires that appropriate technology be developed and used.

The warrantage system offers an excellent opportunity to farmers to get better prices for their grain products like sorghum and millet, to have access to cash credit and to purchase the needed inputs for increasing their agricultural productivity. The example from Mali given in this chapter showed clearly that farmers can obtain great benefits by practising the warrantage system. There is, however, a need to strengthen farmers' organizations and assist them to establish effective linkages with financial stakeholders (commercial 
banks, etc.) for additional funding. Income-generating activities and options during the dry season should be made available to farmers so that they can make better use of the cash loan that they obtained from stocking their grains in the warrantage stores.

\section{Conclusions}

The fertilizer microdosing technology has shown its potential in all the three countries, namely Burkina Faso, Mali and Niger where it was tested, demonstrated and promoted. Overall millet and sorghum grain yields were $50-120 \%$ higher with microdosing than with the earlier recommended fertilizer broadcasting rates and farmers' traditional practices. Microdosing coupled with the warrantage system (credit scheme and input shops) is an entry point for the green revolution in Africa. It is a simple but efficient technology that is readily accessible by farmers. Farmers achieved net profits greater than $130 \%$ from microdosing than with their traditional practice or the broadcasting method.

In spite of the encouraging results that were presented in this chapter, there is a need to address some issues that could make the technology more robust and increase its adoption rate by resource-poor farmers in sub-Saharan Africa. Research should be pursued to investigate the possible soil mining issue, the interaction between improved varieties and microdosing, the water $\times$ microdosing interaction, the effect of input shops on the intensity of fertilizer use and crop productivity, and the mechanization of microdosing as a strategy to reduce labour costs. In our efforts to scale up and out the technology, we will emphasize capacity-building activities to strengthen farmers' associations, link farmers' organizations to decentralized financial systems and banks, improve on the various infrastructures for the warrantage system and facilitate exchange visits between farmers and across countries. Monitoring and evaluation of these activities will be intensified.

Acknowledgements The authors express their gratitude to USAID and CORAF/AfDB for providing funding to implement the project activities in Burkina Faso, Mali and Niger. We thank all the farmers, farmers' organizations and research and development partners and NGOs for their active involvement in the execution of the field activities.

\section{References}

Bationo A, Lompo F, Koala S (1998a) Research on nutrient flows and balances in West Africa: state-of-the art. Agric Ecosyst Environ 71:19-35

Bationo A, Ndjeunga J, Bielders C, Prabhakar VR, Buerkert A, Koala S (1998b) Soil fertility restoration options to enhance pearl millet productivity on sandy Sahelian soils in southwest Niger. In: Lawrence P, Renard G, von Oppen M (eds) Proceedings of an international workshop on the evaluation of technical and institutional options for small farmers in West Africa, University of Hohenheim, Stuttgart, Germany. Margraf Verlag, Weikersheim, Germany, pp 93-104, 21-22, April

Breman H (1990) No sustainability without external inputs. SubSaharan Africa; beyond adjustment. Africa seminar. Ministry of Foreign Affairs, DGIS, The Hague, The Netherlands, pp 124-134

Buerkert A, Hiernaux P (1998) Nutrients in the West African Sudano-Sahelian zone: losses, transfers and role of external inputs. J Plant Nutr Soil Sci 161:365-383

Sivakumar MVK (1992) Climate changes and implications for agriculture in Niger. Climate Change 20:297-312

Stoorvogel JJ, Smaling EMA (1990) Assessment of soil nutrient depletion in sub-Saharan Africa: 1983-2000. Report 28. Wageningen. The Winand Staring Center for Integrated Land, Soil and Water Research (SC-DLO), Wageningen, The Netherlands

Tabo R, Bationo A, Bruno G, Ndjeunga J, Marcha D, Amadou B, Annou MG, Sogodogo D, SibiryTaonda JB, Ousmane H, Diallo MK, Koala S (2007) Improving cereal productivity and farmers, income using a strategic application of fertilizers in West Africa, pp 201-208. In: Bationo A, Waswa BS, Kihara J, Kimetu J (eds) Advances in integrated soil fertility management in sub-Saharan Africa: Challenges and opportunities, $1091 \mathrm{pp}$

Tabo R, Bationo A, Diallo MK, Hassane O, Koala S (2006) Fertilizer micro-dosing for the prosperity of small-scale farmers in the Sahel: Final report. Global theme on agroecosystems report No. 23. P.O. Box 12404, International Crops Research Institute for the Semi-Arid Tropics, Niamey, Niger, 28pp

Traore F (1974) Etude de la fumure azotée intensive des céréales et du rôle spécifique de la matière organique dans la fertilité des sols du Mali. Agron Trop 29:567-586

Van Keulen H, Breman H (1990) Agricultural development in the West African Sahelian region: a cure against land hunger? Agric Ecosyst Environ 32:177-197 